OPEN ACCESS

Edited by:

David K. Wright,

Seoul National University, South Korea

Reviewed by:

Nadia Solovieva,

University College London,

United Kingdom

Nicolas Tribovillard,

Lille University of Science and

Technology, France

${ }^{*}$ Correspondence:

K. R. Chandana

chandana9murthy@gmail.com

Specialty section

This article was submitted to

Quaternary Science, Geomorphology and Paleoenvironment,

a section of the journal

Frontiers in Earth Science

Received: 04 August 2017 Accepted: 05 October 2017

Published: 24 October 2017

Citation:

Chandana KR, Bhushan R and Jull AJT (2017) Evidence of Poor Bottom Water Ventilation during LGM

in the Equatorial Indian Ocean.

Front. Earth Sci. 5:84.

doi: 10.3389/feart.2017.00084

\section{Evidence of Poor Bottom Water Ventilation during LGM in the Equatorial Indian Ocean}

\author{
K. R. Chandana ${ }^{1 *}$, Ravi Bhushan ${ }^{1}$ and A. J. T. Jull ${ }^{2}$ \\ ${ }^{1}$ Geosciences Division, Physical Research Laboratory, Ahmedabad, India, ${ }^{2}$ NSF Arizona AMS Laboratory, University of \\ Arizona, Tucson, AZ, United States
}

Multi-proxy approach for the reconstruction of paleo-redox conditions is attempted on a radiocarbon $\left({ }^{14} \mathrm{C}\right)$ dated sediment core near the equatorial Indian Ocean. Based on the behavior and distribution of redox sensitive and productivity proxies, study demonstrates prevalence of anoxic bottom water conditions during LGM due to poorly ventilated bottom waters augmented by high surface productivity resulting in better preservation of organic carbon (OC). During early Holocene, the equatorial Indian Ocean witnessed high sedimentation rates resulting in high organic carbon $(\mathrm{OC})$ with depleted redox sensitive elements thereby causing better preservation of OC. The study underscores poor bottom water ventilation during LGM and preservation of $\mathrm{OC}$ as a result of high sedimentation rate in early Holocene.

Keywords: LGM, anoxic bottom water, holocene period, redox sensitive elements, organic carbon, GEOTRACES

\section{INTRODUCTION}

The depositional conditions in the marine environment can be oxic, suboxic and anoxic based on the presence or absence of oxygen at the sediment-water interface. Redox sensitive elements have demonstrated their potential in deciphering the past bottom water anoxic condition in the oceanic basin. The elemental concentrations in marine sediments are mainly controlled by various processes such as terrestrial influx, biological processes, in-situ precipitation, and/or by hydrothermal activity (Pattan and Pearce, 2009). The oxygen concentration in bottom water plays an important role in altering oxygen gradients in the sedimentary column and this in turn depends upon change in deep water circulation during the past glacial-interglacial period (Bareille et al., 1998; Ahmad et al., 2008; Pattan and Pearce, 2009).

Based on the dissolved oxygen $\left(\mathrm{O}_{2}\right)$ and/or hydrogen sulfide $\left(\mathrm{H}_{2} \mathrm{~S}\right)$ concentrations, the sedimentary environment has been categorized as oxic $\left(>2.0 \mathrm{ml} \mathrm{O}_{2} \mathrm{l}^{-1}\right)$, suboxic/dysoxic $(2.0-$ $\left.0.2 \mathrm{ml} \mathrm{O}_{2} \mathrm{l}^{-1}\right)$, and anoxic/euxinic $\left(0.2-0 \mathrm{ml} \mathrm{O}_{2} \mathrm{l}^{-1}\right)$ (Tyson and Pearson, 1991). In addition to oxygen concentration, the labile organic matter $(\mathrm{OM})$ also controls the redox element cycling in the bottom water. Under oxic conditions, aerobic bacteria utilizes dissolved oxygen for OM degradation, while with decrease in dissolved $\mathrm{O}_{2}$, the degradation continues using secondary oxidant sources leading to oxygen deficient conditions in the water column. Redox sensitive elements are often portrayed as classic tool to reconstruct the past depositional conditions in the bottom water (Brumsack, 1980, 2006; Calvert and Pedersen, 1993; Dean et al., 1999; Algeo and Tribovillard, 2009). The redox elements such as Mo, V, Cr, Mn have different solubilities in marine water depending on the redox conditions and has been commonly used to trace anoxic conditions near the sediment-water interface (Agnihotri et al., 2003; Rimmer, 2004; Algeo and Lyons, 2006; Tribovillard et al., 2006; Banerji et al., 2016). In oxic waters, Mn gets precipitated as Mn-oxides 
into the sediments, while $\mathrm{V}$ as vanadate oxyanions $\left(\mathrm{HVO}_{4}^{2-}\right.$ and $\left.\mathrm{H}_{2} \mathrm{VO}^{4-}\right)$, Mo as molybdate $\left(\mathrm{MoO}_{4}^{2-}\right) \mathrm{Cr}$ as chromate anions $\left(\mathrm{CrO}_{4}^{2-}\right)$ are present in dissolved form. Unlike $\mathrm{Mn}$, all other redox sensitive elements are conservative in oxygenated waters with a constant concentration, but under anoxic conditions they are highly enriched in sediments especially where bottom water oxygen is zero (Calvert and Pedersen, 1993, 1996; Algeo and Lyons, 2006; Tribovillard et al., 2006; Pattan and Pearce, 2009).

The Indian Ocean being situated in mid-way of global conveyor belt, between the Atlantic deep water formation and return of surface water from the Pacific, deep waters in the Indian Ocean are ventilated only from south (Piotrowski et al., 2009). Presently, in the Northern Indian Ocean (NIO), intermediate depths comprises high salinity water masses such as Red Sea, Persian Gulf Waters and contribution from Pacific Ocean through Indonesian Archipelago at depths of 500 to $1,500 \mathrm{~m}$ (Kallel et al., 1988). The Indian Ocean deep water is mainly North Atlantic Deep Water (NADW) between $\sim 2,000-4,000 \mathrm{~m}$ relatively rich in dissolved oxygen compared to Antarctic Bottom Water (AABW) found below $\sim 4,000 \mathrm{~m}$ (Sarkar et al., 1993). Various studies have shown that during last glacial period, the formation rate of the NADW was reduced, while the AABW remained unchanged or probably enhanced (Duplessy et al., 1988; Ahmad et al., 2008).

High resolution paleoclimatic records from late-Quaternary sediments has become increasingly useful tool for deciphering variability in sedimentary paleoproductivity and paleoredox conditions (Ivanochko and Pedersen, 2004; Hendy and Pedersen, 2005; Dean et al., 2006; Cartapanis et al., 2011). A study based on organic carbon (OC) and Mn concentrations from the Arabian Sea, suggested deposition of sediments under oxic conditions during deglacial period as a result of lower productivity and high Mn concentration (Shetye et al., 2014). The prevalence of near anoxic bottom water conditions during glacial cycle has been demonstrated based on $\mathrm{U}$ and OC content in marine sediment from the SE Arabian Sea (Sarkar et al., 1993). Study based on Mo and V concentrations near the SE Arabian Sea suggested prevalence of suboxic conditions during LGM (Pattan and Pearce, 2009). During LGM, reduced proportion of NADW and increased proportion of AABW near the equatorial Indian Ocean has been inferred on the basis of $\mathrm{Nd}$-isotopic composition of ferromagnese oxides and $\delta^{13} \mathrm{C}$ of foraminifera implying a major trigger in the development of oxygen deficient bottom conditions (Piotrowski et al., 2009). There have been substantial studies indicating the development and persistence of oxygen deficient conditions in the Northern Indian Ocean that are related to either productivity or change in bottom water conditions (Naqvi, 1987; Pailler et al., 2002; Rao et al., 2010). However, there remains unaddressed issues on the simultaneous signatures of productivity and bottom water anoxia on redox sensitive elements. Thus, to address the role of productivity and thermohaline ventilation during glacial-interglacial periods, a sediment core (SK-304A/05) from the intermixing zone of two distinct basins of NIO near the equatorial region was geochemically investigated. This study attempts to substantiate the influence of both productivity and the bottom water ventilation during glacialinterglacial period near the equatorial region of NIO. The objectives of the present study is (i) to reconstruct the redox conditions during glacial-interglacial periods and (ii) to identify the variations in the bottom water oxygen conditions with its causative mechanism during the last $25 \mathrm{ka}$ years BP.

\section{PRESENT DAY OCEANOGRAPHIC SETTING}

The Northern Indian Ocean is unique compared to the other oceans due to its topographical setting as it comprises two basins i.e., the Arabian Sea and the Bay of Bengal being separated by Indian subcontinent. The land-ocean thermal contrast leads to seasonal reversal of winds. During summer (June-September) the monsoonal winds are south-westerly (SW) and during winter (November-February) the monsoonal winds are north-easterly (NE) (Tomczak and Godfrey, 2003). In response to wind, surface currents also reverses its direction in the equatorial Indian Ocean. During summer monsoon, a branch of Somali current (SC) at $4^{\circ}$ turns offshore and supplies the summer monsoon current (SMC) flowing eastward. In addition to SC, the SMC also receives water from southward flowing West Indian Coastal Current (WICC) (Tiwari et al., 2006). As SMC reaches Sri Lanka, it turns northward to Bay of Bengal by flowing around the cyclonic Sri Lanka Dome (SD) and feeding the northeastward flowing East Indian Coast Current (EICC) (Tiwari et al., 2006). Thus, the SMC along with the WICC flows from west to east transporting highly saline water from the Arabian Sea to the Bay of Bengal. During winter monsoon, EICC reverses its direction and flows in southwest direction feeding low salinity water to the west flowing northeast monsoon current (NMC), which in turn contributes to northward flowing WICC (Schott and McCreary, 2001). Thus, these currents play a crucial role in nutrient distribution and chlorophyll concentrations in the equatorial regions (Vidya et al., 2013).

Geochemical investigations have shown that the equatorial Indian Ocean, off Sri Lanka is largely composed of calcareous and smectite clays (Nath, 2001). The sediment trap study carried out for the measurement of biogenic fluxes in the Northern Indian Ocean found predominance of opal fluxes at western Arabian Sea and the Bay of Bengal. But the eastern Arabian Sea, the southern Bay of Bengal (SBBT), and the equatorial Indian Ocean (EIOT) traps are dominated by carbonate fluxes (Ramaswamy and Gaye, 2006). Strong seasonality in the biogenic flux has been observed at SBBT while EIOT remained deprived of such seasonal variations (Vidya et al., 2013).

\section{METHODOLOGY}

A $\sim 410 \mathrm{~cm}$ gravity core (SK-304A/05; water depth-3,408 m) was raised off Srilanka $\left(05^{\circ} 45.622^{\prime} \mathrm{N} ; 79^{\circ} 24.763^{\prime} \mathrm{E}\right)$ in the equatorial Indian Ocean during the ORV Sagar Kanya cruise SK304 in March 2013 (Figure 1). The core was sub-sampled at $1 \mathrm{~cm}$ 


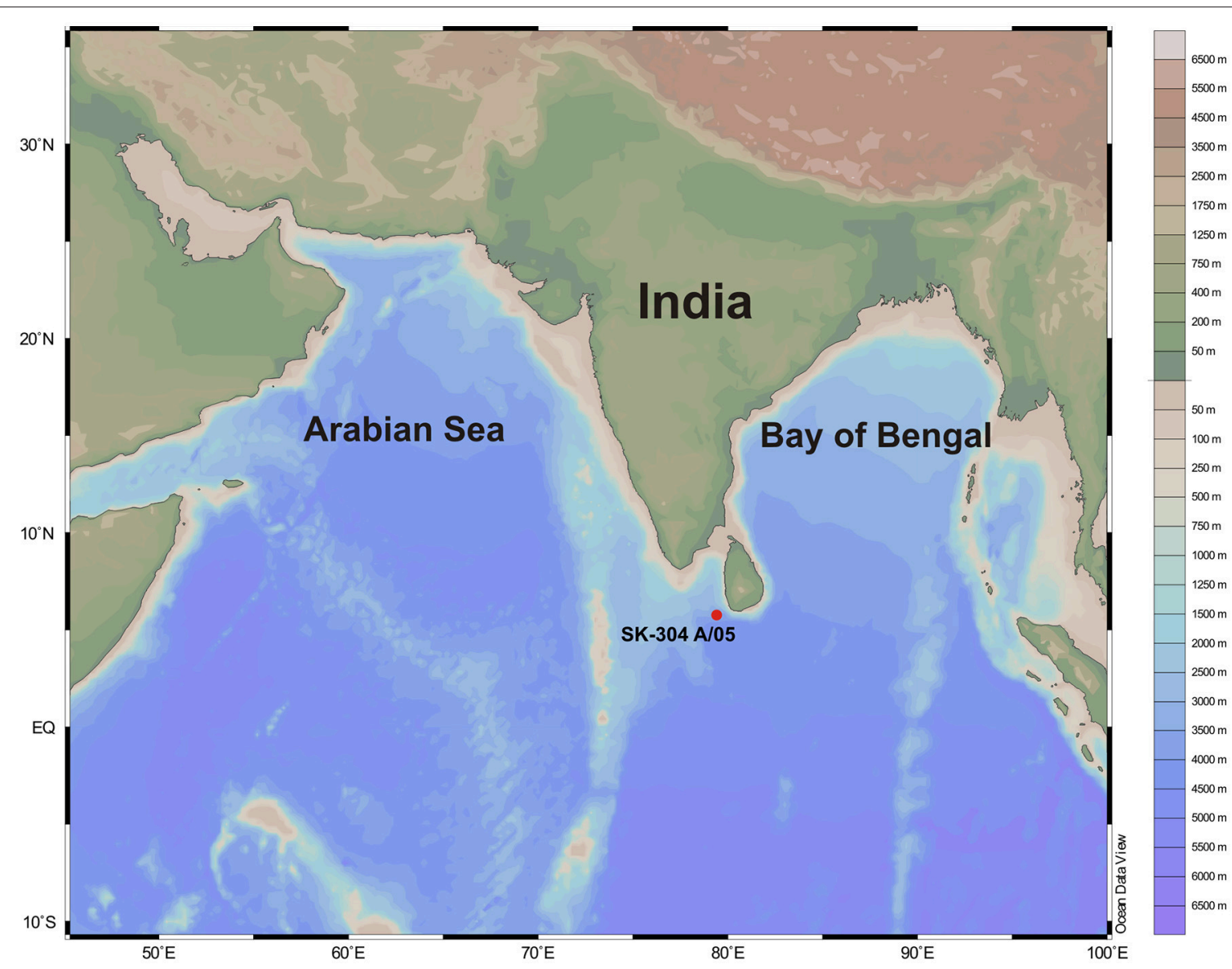

FIGURE 1 | Bathymetry map of Northern Indian Ocean with SK-304A/05 sediment core location retrieved during onboard ORV Sagarkanya. The sediment core lies at the mixing zone of the Arabian Sea and the Bay of Bengal near equatorial region.

interval with non-metallic knife to avoid metallic contamination and kept in a clean ziplock bags till further analysis. Subsamples were oven dried at $80^{\circ} \mathrm{C}$ and finely powdered with the help of agate mortar and pestle for its biogenic, geochemical and isotopic analysis.

The chronology for the upper $200 \mathrm{~cm}$ of the core was established based on nine AMS radiocarbon dates $\left({ }^{14} \mathrm{C}\right)$ analyzed at NSF-AMS facility of Arizona University, USA on handpicked mixed planktonic foraminifera from different depths. The ${ }^{14} \mathrm{C}$ dates were calibrated by Calib 7.0.2 using Marine13 calibration curve (Stuiver et al., 1998; Reimer et al., 2009, 2013) and were corrected with a reservoir age correction of $\Delta \mathrm{R} 60 \pm 52$ years (Dutta et al., 2001; Southon et al., 2002).

In order to measure the trace elemental concentrations, $\sim 300 \mathrm{mg}$ of the dried and crushed samples was subjected to closed digestion by treating it with acid mixture $\left(\mathrm{HNO}_{3}, \mathrm{HCl}\right.$, and HF) in microwave digestion system (Milestone, Start D). Trace elemental ( $\mathrm{Ti}, \mathrm{Mo}, \mathrm{V}, \mathrm{Cr}, \mathrm{Co}, \mathrm{Mn}$ ) concentrations were measured by aspirating the digested solution in ICP-MS (Thermo-X series2). The accuracy and precision for the analysis were monitored by repeat measurements of reference sediment standards (marine sediment standards MAG-1 and NOVA) and was found to be better than \pm 6 and $\pm 4 \%$ respectively. Calcium carbonate $\left(\mathrm{CaCO}_{3}\right)$ was analyzed on Coulometer (UIC Coulometer, Model 5012 ) with a precision of $\sim 2 \%$. Total organic carbon (OC) and total nitrogen (TN) was measured using NC Elemental Analyzer (Flash 2000) with a precision better than 0.2 and 2\% respectively (Bhushan et al., 2001).

\section{RESULTS}

\section{Chronology}

Table 1 summarizes detailed AMS ${ }^{14} \mathrm{C}$ chronology results of the studied sediment core SK-304A/05 retrieved from the equatorial Indian Ocean. The reconstructed age-depth model for the sediment core based on the calibrated radiocarbon dates of foraminifers at various depths (upper $200 \mathrm{~cm}$ section) provides paleoclimatic records for the last $25 \mathrm{ka}$ years BP (Figure 2). The sediment deposition rate at the core varies from $\sim 5.0$ to $13.8 \mathrm{~cm} \cdot \mathrm{ka}^{-1}$. The highest and the lowest sedimentation rates were observed between $\sim 8$ to 11 ka years $\mathrm{BP}$ and $\sim 13.5$ to 19.5 ka years BP respectively. An average sedimentation rate of $\sim 8 \mathrm{~cm} \cdot \mathrm{ka}^{-1}$ was observed for the studied sediment core (Figure 2). The late-Quaternary period has been broadly 
TABLE 1 | Calibrated radiocarbon ages for the sediment core SK-304A/05.

\begin{tabular}{|c|c|c|c|c|c|c|}
\hline S.No. & Sample ID & $\begin{array}{l}\text { Laboratory } \\
\text { ID }\end{array}$ & $\begin{array}{l}\text { Depth } \\
\text { (cm) }\end{array}$ & $\begin{array}{l}\text { Radiocarbon } \\
\text { age (year BP) }\end{array}$ & $\begin{array}{r}\text { Calibra } \\
1 \sigma \text { age }\end{array}$ & $\begin{array}{l}\text { ted age } \\
\text { range }\end{array}$ \\
\hline 1 & PRL-AS-01 & AA104059 & 4 & $2,793 \pm 32$ & 2,338 & 2,528 \\
\hline 2 & PRL-AS-02 & AA104060 & 11 & $3,209 \pm 32$ & 2,844 & 3,013 \\
\hline 3 & PRL-AS-03 & AA104061 & 21 & $4,173 \pm 33$ & 4,071 & 4,257 \\
\hline 4 & PRL-AS-04 & AA104062 & 40 & $5,787 \pm 35$ & 6,050 & 6,217 \\
\hline 5 & PRL-AS-05 & AA104063 & 60 & $8,014 \pm 38$ & 8,347 & 8,476 \\
\hline 6 & PRL-AS-07 & AA104065 & 101 & $10,372 \pm 44$ & 1,1192 & 11,427 \\
\hline 7 & PRL-AS-08 & AA104066 & 119 & $12,172 \pm 49$ & 1,3459 & 13,648 \\
\hline 8 & PRL-AS-09 & AA104067 & 149 & $16,642 \pm 63$ & 1,9399 & 19,639 \\
\hline 9 & PRL-AS-10 & AA104068 & 201 & $21,910 \pm 120$ & 25,646 & 25,881 \\
\hline
\end{tabular}

divided into Last Glacial Maxima (LGM: 22.5-17.5 ka years BP), Deglacial Period (DP: 17.5-11 ka years BP), and Holocene Period (HP: 11-Present) (Rao et al., 2010).

\section{Geochemical Proxies}

The downcore geochemical signatures were studied to reconstruct the paleoproductivity and paleoredox conditions prevailed during the last $25 \mathrm{ka}$ years BP. Generally, $\mathrm{Al}$ and $\mathrm{Ti}$ are considered as extremely resistant to weathering and conservative elements as they remain unaffected due to changes in redox conditions (Nesbitt and Markovics, 1997; Wei et al., 2003) and has been extensively used to estimate the terrigenous material in the sedimentary environment (Murray and Leinen, 1993, 1996; Schroeder et al., 1997; Klump et al., 2000). Under certain circumstances, $\mathrm{Al}$ can form as a result of authigenic clay mineral formation (Timothy and Calvert, 1998) or it may get scavenged as hydroxides coating over biogenic particles (Murray and Leinen, 1996). Similar to Al, Si is also associated with biogenic opal and this limits its use as terrestrial tag. Thus, in the present study, the elements have been normalized by $\mathrm{Ti}$ instead of $\mathrm{Al}$ and $\mathrm{Si}$. The $\mathrm{Ti}$ concentration in the studied sediment core varies between 1,923-3,585 ppm (Figure 3). Sedimentary $\mathrm{OC}$ and $\mathrm{CaCO}_{3}$ are important constituents of the biogenic fraction of the marine sediments, and thus can be used as a proxy for paleoproductivity. However, OC and $\mathrm{CaCO}_{3}$ constitute only a fraction of total biological productivity in the surface oceanic water due to its biological degradation during its passage through the water column (Tribovillard et al., 2006). The $\mathrm{OC}$ and $\mathrm{CaCO}_{3}$ concentration ranges from $1.28-5.14$ to $25.30-48.92$ wt\% respectively (Figures 4, 5). High OC concentration results in enhanced bacterial degradation causing oxygen deficient conditions (suboxic, anoxic, and euxinic) in the water column and at sediment-water interface. Under such oxygen deficient conditions at the sediment-water interface, the behavioral pattern of redox sensitive elements is generally used to comprehend the paleoredox conditions persisted at the time of sediment deposition. The elemental concentration of $\mathrm{V}, \mathrm{Mn}, \mathrm{Cr}, \mathrm{Mo}, \mathrm{Ni}$, Co that has been used to access the paleoredox conditions ranges from 45-110, 204-380, 45-91, 0.6-2.8, 35-90, and 7-15 ppm respectively (Figures 3, 4).

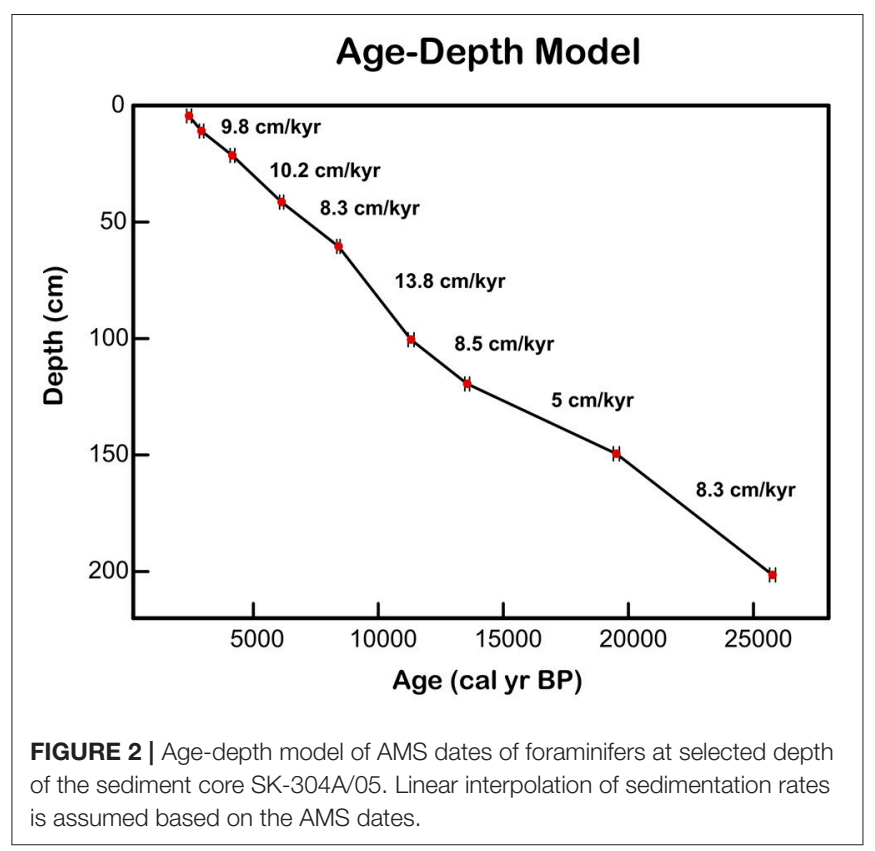

\section{DISCUSSION}

The organic matter (Shetye et al., 2014) and Fe- and Mnoxyhydroxides (Tribovillard et al., 2006) are the major sources for the transportation of the trace elements from water column to the sediments. In oxic and anoxic environments, the trace elements behave differently based on their oxidation states which is influenced by the redox conditions (Shetye et al., 2014).

\section{Biogenic Productivity during Glacial Interglacial Periods}

Consistently high values for the $\mathrm{CaCO}_{3}$ (Figure 4) were observed during LGM with gradually declining trend during the early Holocene and subsequently marginal increase during the late Holocene. Such consistently high values suggest high calcareous productivity during LGM. Two conspicuous peaks of OC (Figure 5) during $\sim 21$ ka years BP and at early Holocene (11-8 ka years BP) has been observed. The early Holocene OC peak corroborates well with the abrupt increase in the sedimentation rate $\sim 13.5 \mathrm{~cm} . \mathrm{ka}^{-1}$ primarily suggesting preservation of OC with efficient burial and not due to abrupt high overhead productivity. The OC peak at $\sim 21 \mathrm{ka}$ years BP corresponding to LGM period, however, resulted due to high productivity and better OC preservation. High OC and $\mathrm{CaCO}_{3}$ observed during LGM can be due to high productivity because of strong $\mathrm{NE}$ monsoonal winds that enhanced nutrient levels in the photic zone (Rostek et al., 1997; Punyu et al., 2014). With the commencement of deglacial period, weakening of NE monsoonal winds led to decrease in productivity during the Holocene period. Thus, high productivity could be one of the factors responsible for triggering reducing conditions at the sediment-water interface (Tribovillard et al., 2006). 


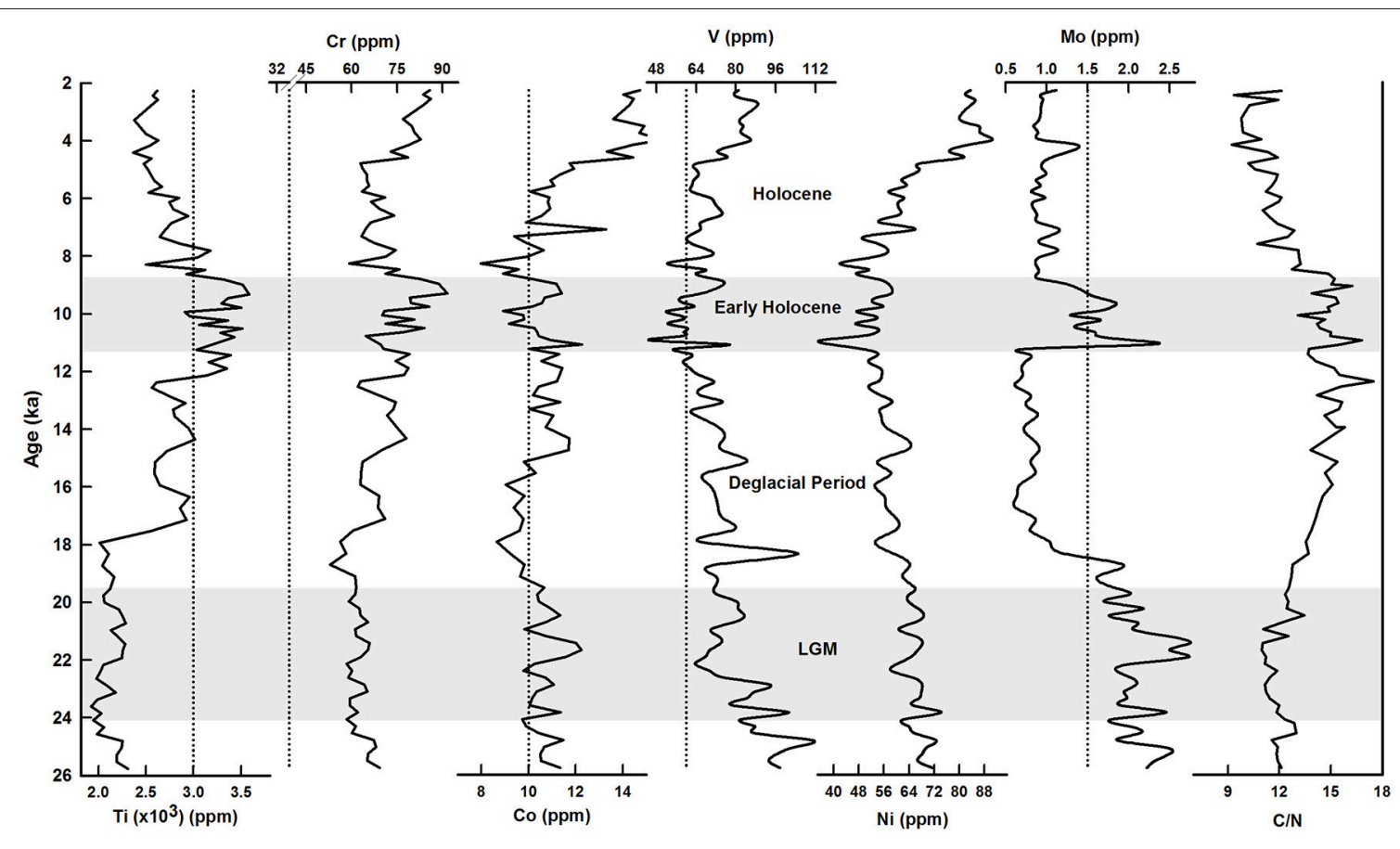

FIGURE 3 | Downcore variation of elemental concentration in the sediment core SK-304A/05 indicates low terrestrial flux during LGM with gradual increasing values during Deglacial and Holocene period. The dotted line in each plot indicates average crustal values for the respective elements.

\section{Redox Proxy with Detrital Affect}

Generally, $\mathrm{Cr}$ is present in the form of $\mathrm{Cr}$ (VI) as mobile chromate anion in oxygenated waters, while under anoxic conditions it gets reduced to $\mathrm{Cr}$ (III), which is very unstable and forms complex cations with humic and fulvic acids. It also gets adsorbed with Fe-Mn oxyhydroxides and transported to the sediments (Calvert and Pedersen, 1993; Tribovillard et al., 2006). Cr also gets transported to the sediments along with the detrital fraction due to its presence in chromite and ferromanganese minerals (Dill et al., 1988; Francois, 1988; Hild and Brumsack, 1998). The average $\mathrm{Cr}$ concentration in the studied sediment core is $\sim 69 \mathrm{ppm}$, much higher than the average crustal value of 35 ppm (Taylor and McLennan, 1995). Synchronous variation in vertical profiles of detrital proxies $\mathrm{Ti}$ and $\mathrm{C} / \mathrm{N}$ along with $\mathrm{Cr}$ has been observed in this study (Figure 3). Consistent low values of $\mathrm{Ti}$ and $\mathrm{Cr}$ till $18 \mathrm{ka}$ years $\mathrm{BP}$ with $\mathrm{C} / \mathrm{N}<12$ suggests reduced terrestrial contribution at the core location due to weakening of summer monsoon (Naidu and Malmgren, 1996; Rashid et al., 2007; Anand et al., 2008). Gradual increase in Ti and $\mathrm{Cr}$ after 18 ka years BP till 8 ka years $\mathrm{BP}$ with $\mathrm{C} / \mathrm{N} \geq 12$ indicates enhanced land-driven clastic fraction to the region instigated by the summer monsoon intensification (Govil and Naidu, 2011). The $\mathrm{Cr}$ concentrations in the studied sediment core is thus a function of changing detrital influx to the region rather than changing redox conditions in the water column and limits its application as redox proxy, but can be a potential proxy to decipher terrestrial influence.

Co has been used as potential tool to decipher paleoredox conditions at the sediment-water interface due to its complex formation with fluvic or humic acid under oxic seawaters (Achterberg et al., 2003). In oxygen deficient waters it can get incorporated into the solid phase authigenic by sulfide formation as Fe sulfides (Algeo and Maynard, 2004; Tribovillard et al., 2006). Co is prone to be influenced by detrital clastic material. The average Co concentration throughout the sediment core is $\sim 11 \mathrm{ppm}$ similar to the average crustal Co value of $10 \mathrm{ppm}$ (Taylor and McLennan, 1995). Near similar values of Co with crustal values suggests its detrital contribution, but marginal enrichment in $\mathrm{Co} / \mathrm{Ti}$ during LGM could be indicative of being a reasonable proxy to decipher past redox conditions.

\section{Redox Proxy with Low Detrital Affect}

Under oxic conditions, vanadium occurs in the form of $\mathrm{V}(\mathrm{V})$ as vanadate species getting adsorbed onto $\mathrm{Mn}-\mathrm{Fe}$ oxyhydroxide (Morford and Emerson, 1999), whereas, Mo remains as unreactive dissolved molybdate species $\left(\mathrm{MoO}_{4}^{2-}\right.$ ) (Emerson and Huested, 1991; Calvert and Pedersen, 1993; Tribovillard et al., 2006; Pattan and Pearce, 2009). Under oxygen deficient conditions, both $\mathrm{V}$ and Mo are removed from the water column and its enrichment in the sediment serves as potential tool to decipher reducing conditions at sediment-water interface (Calvert and Pedersen, 1993; Tribovillard et al., 2006; Pattan and Pearce, 2009).

The average $\mathrm{V}$ and Mo concentrations in the present study, are $\sim 72$ and $\sim 1.4 \mathrm{ppm}$ respectively. The co-occurrence of high values for $\mathrm{Mo}, \mathrm{V}, \mathrm{OC}, \mathrm{Mo} / \mathrm{Ti}$, and V/Ti observed during LGM suggests prevalence of anoxic conditions at the sediment-water interface. Synchronous decline in $\mathrm{Mo}, \mathrm{V}, \mathrm{OC}, \mathrm{Mo} / \mathrm{Ti}$, and $\mathrm{V} / \mathrm{Ti}$ 


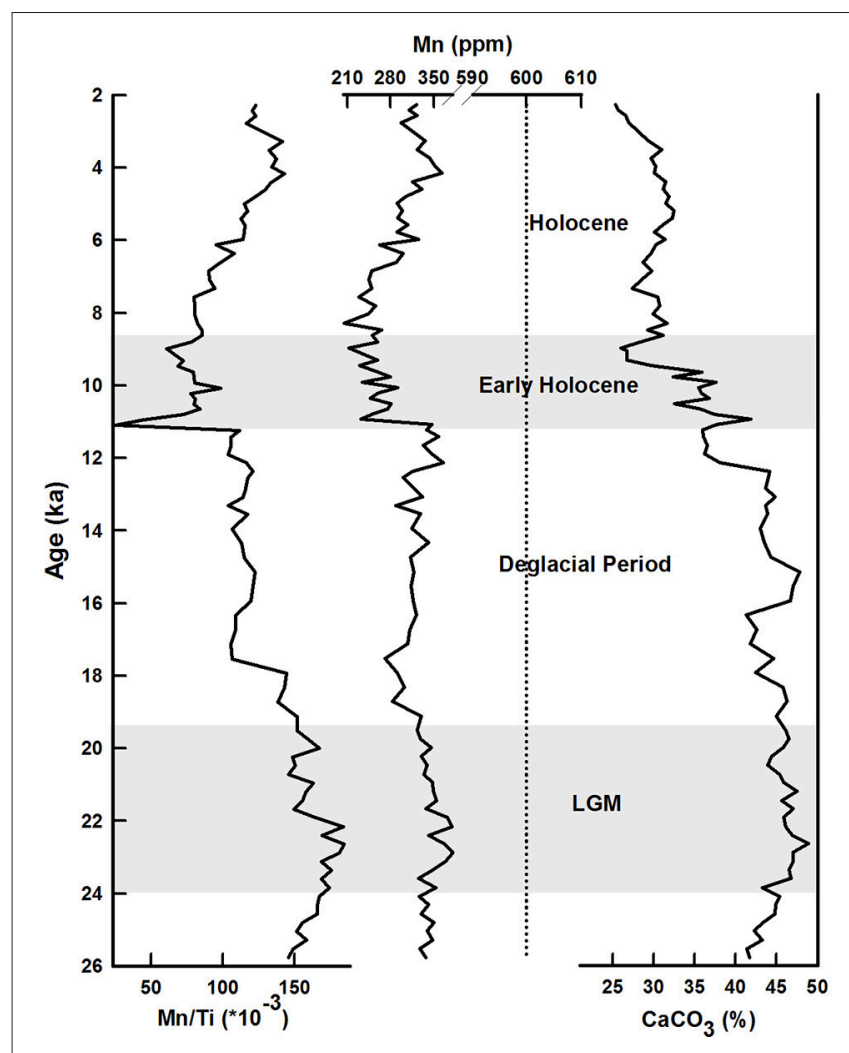

FIGURE 4 | Downcore variation of $\mathrm{Mn}, \mathrm{CaCO}_{3}$, and $\mathrm{Mn} / \mathrm{Ti}$ indicates that $\mathrm{Mn}$ forms authegenic carbonate in presence of $\mathrm{CaCO}_{3}$.

during deglacial period indicates resumption of oxic conditions at the sediment-water interface (Figures 3, 5). Unlike $\mathrm{V}$ and $\mathrm{V} / \mathrm{Ti}$, a conspicuous enrichment in $\mathrm{OC}, \mathrm{Mo}$, and $\mathrm{Mo} / \mathrm{Ti}$ has been observed during early Holocene between 11 and 8 ka years $\mathrm{BP}$. This can be corroborated well with the high sedimentation rate of $\sim 13.5 \mathrm{~cm} . \mathrm{ka}^{-1}$ during early Holocene. This underpins better preservation of organic matter as a function of high sedimentation rate, while enhanced $\mathrm{Mo}$ and $\mathrm{Mo} / \mathrm{Ti}$ plausibly resulted due to the formation of Mo-S complexes (Tribovillard et al., 2004).

In oxygenated waters, $\mathrm{Mn}$ is present as $\mathrm{Mn}$ (II) which is highly unstable and gets oxidized to insoluble Mn (IV) (Mnoxyhydroxides) and is delivered to the sediments (Tribovillard et al., 2006). Manganese thus plays a significant role in transferring trace metals by scavenging them from the water column to the ocean bottom. However, during anoxic conditions, at the sediment-water interface, the dissolution of oxides and hydroxides releases $\mathrm{Mn}$ (II) back to the waters (Rajendran et al., 1992). Identical vertical distribution in $\mathrm{V} / \mathrm{Ti}$ and $\mathrm{Mn} / \mathrm{Ti}$ suggests adsorption of vanadate onto Fe- and Mn-oxyhydroxides (Calvert and Piper, 1984). The co-occurrence of high values of $\mathrm{Mo} / \mathrm{Ti}$ and $\mathrm{V} / \mathrm{Ti}$ during LGM suggests anoxic conditions, which results in dissolution of oxides and hydroxides and releasing Mn (II) back to the waters (Rajendran et al., 1992) leading to depletion of $\mathrm{Mn}$ concentration in the sediment.
Contrarily, the simultaneous enrichment of $\mathrm{V} / \mathrm{Ti}$ and $\mathrm{Mo} / \mathrm{Ti}$ with $\mathrm{Mn} / \mathrm{Ti}$ is observed along with the enhancement of $\mathrm{CaCO}_{3}$ during LGM (Figure 4). Such conspicuous behavior of $\mathrm{Mn}$ can be attributed to trapping of $\mathrm{Mn}$ in authigenic Mn-carbonates during its export to the sediments (Pedersen and Price, 1982; Morford et al., 2001; Tribovillard et al., 2006).

Similar to $\mathrm{V} / \mathrm{Ti}$ and $\mathrm{Mo} / \mathrm{Ti}$, enhanced values of $\mathrm{Ni} / \mathrm{Ti}$ during LGM indicate its role as a redox sensitive proxy. Generally, Ni acts as a micronutrient and occurs as soluble cation either as $\mathrm{Ni}^{2+}$ in soluble nickel carbonate $\left(\mathrm{NiCO}_{3}\right)$ or $\mathrm{NiCl}^{+}$in oxic environments (Calvert and Pedersen, 1993; Whitfield, 2001). The average Ni concentration $(60 \mathrm{ppm})$ in the present study is higher than the average crustal abundance of 20 ppm (Taylor and McLennan, 1995). Simultaneous enhancement in Ni/Ti and OC during LGM suggest scavenging of $\mathrm{Ni}$ by organic matter in the water column (Piper and Perkins, 2004; Naimo et al., 2005). During organic matter degradation under extreme reducing conditions (sulfate redution), Ni generally precipitates as NiS in sediments. Therefore, high Ni/Ti along with OC during LGM implies deposition of the sediments under anoxic conditions. During deglacial period (17.5-10 ka years BP), synchronous decrease in $\mathrm{Ni} / \mathrm{Ti}$ ratio and $\mathrm{OC}$ suggests oxic conditions in the sediment-water interface (Figure 5).

High $\mathrm{OC}$ and $\mathrm{CaCO}_{3}$ values observed in the sediment core during LGM indicate enhanced productivity, whereas abrupt enhancement of OC during early Holocene (11-8 ka years BP) can be attributed to better preservation with high sedimentation rate. Similarly, enhanced redox sensitive elements (Mo/Ti, V/Ti, Ni/Ti) along with high OC during LGM suggests anoxic conditions triggered by high bacterial degradation of organic matter at the sediment-water interface. Unlike $\mathrm{CaCO}_{3}$ and redox sensitive elements, marginal enrichment in the $\mathrm{OC}$ is observed at $\sim 21$ ka years $\mathrm{BP}$ which later declined, but $\mathrm{CaCO}_{3}$ and redox sensitive elements showed consistently high values with declining pattern until $11 \mathrm{ka}$ years BP. Moreover, the OC values are nearly similar at LGM and the early Holocene. Thus, during LGM, anoxic conditions persisted as indicated by redox sensitive elements, while no decipherable reducing conditions occurred during the early Holocene (11-8 ka years BP). A similar observation in SE Arabian Sea suggests high productivity induced low oxygenated bottom water conditions during LGM (Rao et al., 2010). In comparison to the present study, it has been reported that the sediments from the equatorial Arabian Sea (Pailler et al., 2002) and SE Arabian Sea (Pattan and Pearce, 2009) never witnessed complete anoxic bottom water conditions, instead a fluctuation between oxic and suboxic conditions has been observed during LGM. While, another study from the SE Arabian Sea suggests near-anoxic conditions probably resulting in enhanced OC preservation and removal of $U$ from seawater during LGM (Sarkar et al., 1993).

Therefore, it can be stated that anomalous high OC values and changing behavior of redox sensitive elements suggests that it is not only the high sedimentation rate or organic matter degradation which influenced the redox elements, but other processes too are responsible for instigating the oxygen deficient conditions at the sediment-water interface during LGM. 


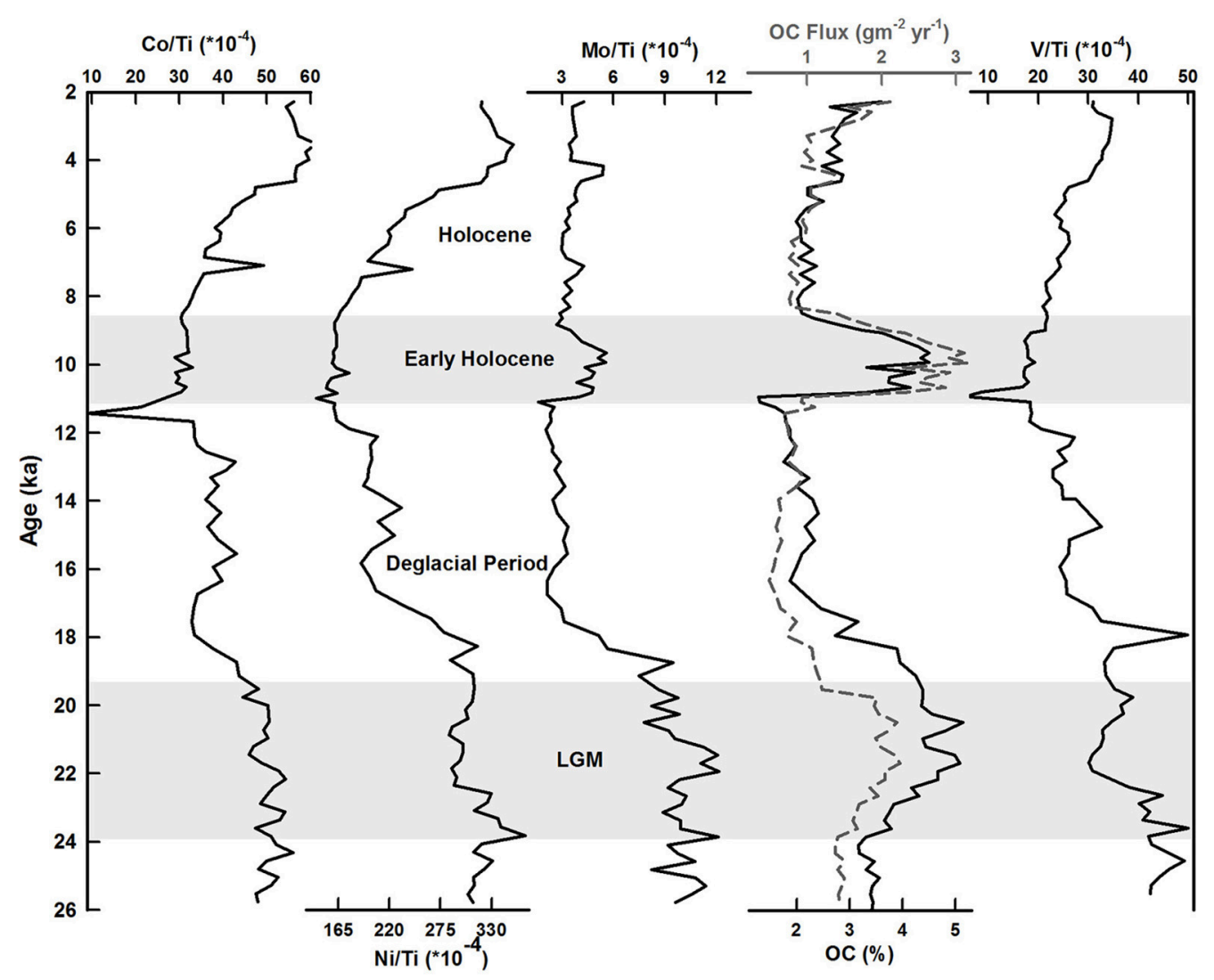

FIGURE 5 | Downcore variation of Ti normalized redox sensitive elements (Co, Ni, V, Mo), OC and OC flux. High values of OC and redox sensitive elements observed during LGM.

\section{Evidence of Anoxic Bottom Waters at LGM}

The redox conditions at the sediment-water interface is mainly controlled by bottom water oxic conditions influenced by deep water circulation and increased oxygen demand for enhanced OC supply and its degradation (Pattan and Pearce, 2009; Pattan et al., 2013). Enhanced overhead productivity leads to greater organic matter export to the sediments. $\mathrm{C} / \mathrm{N}$ ratios has been extensively used to decipher the provenance of organic matter, i.e., values of $\mathrm{C} / \mathrm{N} \leq 12$ and $\mathrm{C} / \mathrm{N} \geq 12$ suggests provenance of marine and terrestrial origin of OC respectively (Hedges and Parker, 1976; Emerson and Hedges, 1988; Meyers, 1997; Bhushan et al., 2001; Pattan et al., 2013). The $\mathrm{C} / \mathrm{N}$ ratio in the present study varies from 9 to 17 with an average of 12 . The $\mathrm{C} / \mathrm{N}$ ratio followed pattern similar to Ti with low values during LGM with gradual increasing trend during the early Holocene followed by marginal decrease till present (Figure 6). Low $\mathrm{C} / \mathrm{N}(\sim 10)$ and high OC $(\sim 5$ wt\%) during LGM suggests reduced contribution of terrestrial OC primarily derived from overhead productivity. Marine OC is more labile and prone to microbial activity leading to oxygen deficient conditions both in water column and sediment-water interface. In the present study, if the enhanced peak of OC is due to high overhead productivity, then similar pattern should have been displayed by the redox sensitive elements during $\sim 21$ ka years BP. However, in the present scenario, the OC peak at $\sim 21$ ka years BP clearly indicates better preservation of OC (Figure 6).

Due to the geographical setup, the deep water in the Indian Ocean is ventilated solely from south (Piotrowski et al., 2009). Previous studies on $\delta^{13} \mathrm{C}$ and $\delta^{18} \mathrm{O}$ isotopic composition of foraminifera suggested significant changes during the glacialinterglacial period in the chemical characteristics of surface and deep water masses (Duplessy, 1982; Naqvi et al., 1994; Schmiedl and Leuschner, 2005; Ahmad et al., 2008). NADW is the main source for deep water ventilation in the Northern Indian Ocean and marginal change in deep water circulation alters the bottom water oxygen conditions. Previous studies have suggested that during LGM, the export of deep water from north Atlantic was reduced, which further compensated increased formation of Southern Ocean deep water (Kallel et al., 1988; Ahmad et al., 2008) and allowed replacement of NADW with AABW penetrating further northward (Curry et al., 1988; Curry and Oppo, 2005).

The present study based on a sediment core raised from a water depth of $3,400 \mathrm{~m}$ demonstrates anoxic conditions during LGM in the equatorial Indian Ocean. Such anoxic conditions were established due to enhanced productivity with 


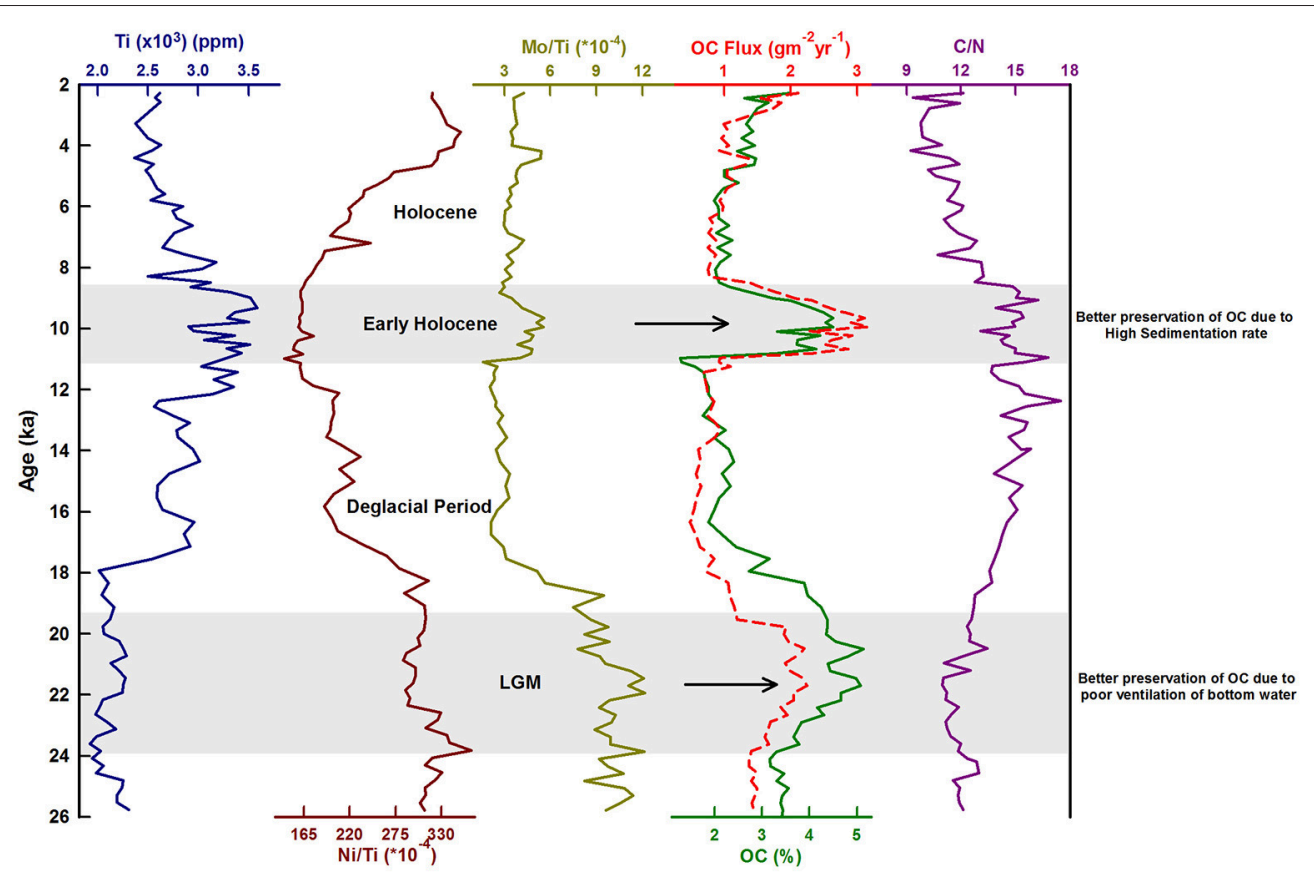

FIGURE 6 | Comparative plot for detrital and redox proxies with OC suggesting preservation of OC during LGM and early Holocene Period.

OC degradation and deep water circulation changes originating from weakly ventilated (poor in $\mathrm{O}_{2}$ and rich $\mathrm{CO}_{2}$ ) Southern Ocean deep waters. This further augmented oxygen deficient conditions causing enhanced preservation of OC. High OC peak at $\sim 21$ ka years BP can be attributed to post depositional preservation of organic matter at the sediment-water interface due to the bottom water anoxic conditions (Figure 6). The present observations of anoxic bottom water due to poor ventilation is further supported by Ahmad et al. (2008) and Piotrowski et al. (2009) from the equatorial Indian Ocean. They suggested weak deep-water ventilation in Northern Indian Ocean as a result of reduced proportion of NADW (poor in $\mathrm{CO}_{2}$ and rich in $\mathrm{O}_{2}$ ) and increased proportion of AABW (rich in $\mathrm{CO}_{2}$ and poor in $\mathrm{O}_{2}$ ) during LGM. During early Holocene (11-8 ka years $\mathrm{BP})$, enhanced $\mathrm{OC}$ with $\mathrm{C} / \mathrm{N}>12(\sim 16)$ suggests terrestrial origin of organic carbon (Figure 6). The OC preservation during the Holocene period without any significant variation in redox sensitive elements is mainly due to high sedimentation rate with deposition under well ventilated bottom water conditions.

\section{CONCLUSIONS}

The behavior of redox sensitive elements has been extensively used to decipher paleo redox conditions at the sediment-water interface. On the basis of investigation of redox sensitive elements and $\mathrm{OC}$ content in a sediment core from the equatorial Indian Ocean, the present study demonstrates prevalence of anoxic conditions during LGM. The anoxic condition in the water column at the sediment-water interface during $\sim 21$ ka years BP is due to the degradation of organic matter exported from enhanced overhead productivity further instigated by poorly ventilated bottom water. This results in post depositional preservation of OC. The early Holocene period (11-8 ka years BP) with increased OC has been attributed to high sedimentation rate supported by high overhead OC flux without any significant variation in the redox sensitive elements. The present study provides a valuable signature of poor bottom water ventilation at the equatorial Indian Ocean during LGM and its role in better OC preservation with concurrent occurrence of high surface productivity.

\section{AUTHOR CONTRIBUTIONS}

All the authors have significantly contributed to bring the manuscript in final form. $\mathrm{RB}$ collected the samples. $\mathrm{KC}$ conducted the experiments and measurements. $\mathrm{RB}$ and $\mathrm{KC}$ compiled the data, interpreted, and prepared the manuscript. AJ provided radiocarbon AMS dates and chronology estimation of the sediment core.

\section{ACKNOWLEDGMENTS}

We are thankful for the support of Ministry of Earth Sciences, Govt. of India under GEOTRACES Project (MOES/36/OOIS. Siber07). We thank cruise participants for their help and support during sediment core collection. We also thank Captain and Crew members of Sagar Kanya and NCAOR for providing logistic support during the cruise. We thank Director, PRL for support. 


\section{REFERENCES}

Achterberg, E. P., Van Den Berg, C. M. G., and Colombo, C. (2003). High resolution monitoring of dissolved $\mathrm{Cu}$ and $\mathrm{Co}$ in coastal surface waters of the western North Sea. Cont. Shelf Res. 23, 611-623. doi: 10.1016/S0278-4343(03)00003-7

Agnihotri, R., Sarin, M. M., Somayajulu, B. L. K., Jull, A. J. T., and Burr, G. S. (2003). Late-Quaternary biogenic productivity and organic carbon deposition in the eastern Arabian Sea. Palaeogeogr. Palaeoclimatol. Palaeoecol. 197, 43-60. doi: 10.1016/S0031-0182(03)00385-7

Ahmad, S. M., Babu, G. A., Padmakumari, V. M., and Raza, W. (2008). Surface and deep water changes in the northeast Indian Ocean during the last $60 \mathrm{ka}$ inferred from carbon and oxygen isotopes of planktonic and benthic foraminifera. Palaeogeogr. Palaeoclimatol. Palaeoecol. 262, 182-188. doi: 10.1016/j.palaeo.2008.03.007

Algeo, T. J., and Lyons, T. W. (2006). Mo-total organic carbon covariation in modern anoxic marine environments: implications for analysis of paleoredox and paleohydrographic conditions. Paleoceanography 21:PA1016. doi: 10.1029/2004PA001112

Algeo, T. J., and Maynard, J. B. (2004). Trace-element behavior and redox facies in core shales of Upper Pennsylvanian Kansas-type cyclothems. Chem. Geol. 206, 289-318. doi: 10.1016/j.chemgeo.2003.12.009

Algeo, T. J., and Tribovillard, N. (2009). Environmental analysis of paleoceanographic systems based on molybdenum-uranium covariation. Chem. Geol. 268, 211-225. doi: 10.1016/j.chemgeo.2009.09.001

Anand, P., Kroon, D., Singh, A. D., Ganeshram, R. S., Ganssen, G., and Elderfield, H. (2008). Coupled sea surface temperature-seawater $\delta 18 \mathrm{O}$ reconstructions in the Arabian Sea at the millennial scale for the last $35 \mathrm{ka}$. Paleoceanography 23, 1-8. doi: 10.1029/2007PA001564

Banerji, U. S., Bhushan, R., and View, G. (2016). Sedimentary records of paleoredox conditions at relict Mudflat of Vasoj, Southern Saurashtra sedimentary records of paleoredox conditions at Relict Mudflat. Earth Sci. India 9, 114-125. Available online at: http://www.earthscienceindia.info/

Bareille, G., Labracherie, M., Bertrand, P., Labeyrie, L., Lavaux, G., and Dignan, M. (1998). Glacial-interglacial changes in the accumulation rates of major biogenic components in Southern Indian Ocean sediments. J. Mar. Syst. 17, 527-539. doi: 10.1016/S0924-7963(98)00062-1

Bhushan, R., Dutta, K., and Somayajulu, B. L. K. (2001). Concentrations and burial fluxes of organic and inorganic carbon on the eastern margins of the Arabian Sea. Mar. Geol. 178, 95-113. doi: 10.1016/S0025-3227(01)00179-7

Brumsack, H. J. (1980). Geochemistry of Cretaceous black shales from the Atlantic Pcean (DSDP Legs 11, 14, 36 and 41). Chem. Geol. 31, 1-25. doi: 10.1016/0009-2541(80)90064-9

Brumsack, H. J. (2006). The trace metal content of recent organic carbon-rich sediments: implications for Cretaceous black shale formation. Palaeogeogr. Palaeoclimatol. Palaeoecol. 232, 344-361. doi: 10.1016/j.palaeo.2005.05.011

Calvert, S. E., and Pedersen, T. F. (1993). Geochemistry of Recent oxic and anoxic marine sediments: implications for the geological record. Mar. Geol. 113, 67-88. doi: 10.1016/0025-3227(93)90150-T

Calvert, S. E., and Pedersen, T. F. (1996). Sedimentary geochemistry of manganese: implications for the environment of formation of manganiferous black shales. Econ. Geol. 91, 36-47. doi: 10.2113/gsecongeo.91.1.36

Calvert, S. E., and Piper, D. Z. (1984). Geochemistry of ferromanganese nodules from DOMES site a, Northern Equatorial Pacific: multiple diagenetic metal sources in the deep sea. Geochim. Cosmochim. Acta 48, 1913-1928. doi: 10.1016/0016-7037(84)90374-0

Cartapanis, O., Tachikawa, K., and Bard, E. (2011). Northeastern Pacific oxygen minimum zone variability over the past 70 kyr: impact of biological production and oceanic ventilation. Paleoceanography 26, 1-17. doi: 10.1029/2011PA002126

Curry, W. B., and Oppo, D. W. (2005). Glacial water mass geometry and the distribution of $\delta^{13} \mathrm{C}$ of $\Sigma \mathrm{CO}_{2}$ in the western Atlantic Ocean. Paleoceanography 20, 1-12. doi: 10.1029/2004PA001021

Curry, W. B., Duplessy, J. C., Labeyrie, L. D., and Shackleton, N. J. (1988). Changes in the distribution of $\delta^{13} \mathrm{C}$ of deep water $\Sigma \mathrm{CO}_{2}$ between the last glaciation and the Holocene. Paleoceanography 3, 317-341. doi: 10.1029/PA003i003p00317

Dean, W. E., Piper, D. Z., and Peterson, L. C. (1999). Molybdenum accumulation in cariaco basin sediment over the past 24 k.y.: a record of water-column anoxia and climate. Geology. 27, 507-510.
Dean, W. E., Zheng, Y., Ortiz, J. D., and van Geen, A. (2006). Sediment Cd and Mo accumulation in the oxygen-minimum zone off western Baja California linked to global climate over the past $52 \mathrm{kyr}$. Paleoceanography 21, 1-13. doi: 10.1029/2005PA001239

Dill, H., Teschner, M., and Wehner, H. (1988). Petrography, inorganic and organic geochemistry of Lower Permian carbonaceous fan sequences ("Brandschiefer Series") - Federal Republic of Germany: constraints to their paleogeography and assessment of their source rock potential. Chem. Geol. 67, 307-325. doi: 10.1016/0009-2541(88)90136-2

Duplessy, J. C. (1982). Glacial to interglacial contrasts in the Northern Indian Ocean. Nature 295, 494-498. doi: 10.1038/295494a0

Duplessy, J. C., Shackleton, N. J., Fairbanks, R. G., Labeyrie, L., Oppo, D., and Kallel, N. (1988). Deepwater source variations during the last climatic cycle and their impact on the global deepwater circulation. Paleoceanography 3, 343-360. doi: 10.1029/PA003i003p00343

Dutta, K., Bhushan, R., and Somayajulu, B. L. K. (2001). $\Delta$ R correction values for the Northern Indian Ocean. Radiocarbon 43, 483-488. doi: $10.1017 /$ S0033822200038376

Emerson, S. R., and Huested, S. S. (1991). Ocean anoxia and the concentrations of molybdenum and vanadium in seawater. Mar. Chem. 34, 177-196. doi: 10.1016/0304-4203(91)90002-E

Emerson, S., and Hedges, J. I. (1988). Processes controlling the organic carbon content of open ocean sediments. Paleoceanography 3, 621-634. doi: 10.1029/PA003i005p00621

Francois, R. (1988). A study on the regulation of the concentrations of some trace metals $(\mathrm{Rb}, \mathrm{Sr}, \mathrm{Zn}, \mathrm{Pb}, \mathrm{Cu}, \mathrm{V}, \mathrm{Cr}, \mathrm{Ni}, \mathrm{Mn}$ and $\mathrm{Mo}$ ) in Saanich Inlet Sediments, British Columbia, Canada. Mar. Geol. 83, 285-308. doi: 10.1016/0025-3227(88)90063-1

Govil, P., and Naidu, P. D. (2011). Variations of Indian monsoon precipitation during the last 32 kyr reflected in the surface hydrography of the Western Bay of Bengal. Quat. Sci. Rev. 30, 3871-3879. doi: 10.1016/j.quascirev.2011.10.004

Hedges, J. I., and Parker, P. L. (1976). Land-derived organic matter in surface sediments from the Gulf of Mexico. Geochim. Cosmochim. Acta 40, 1019-1029. doi: 10.1016/0016-7037(76)90044-2

Hendy, I. L., and Pedersen, T. F. (2005). Is pore water oxygen content decoupled from productivity on the California Margin? Trace element results from Ocean Drilling Program Hole 1017E, San Lucia slope, California. Paleoceanography 20, 1-12. doi: 10.1029/2004PA001123

Hild, E., and Brumsack, H. J. (1998). Major and minor element geochemistry of Lower Aptian sediments from the NW German Basin (core Hohenegglesen KB 40). Cretac. Res. 19, 615-633. doi: 10.1006/cres.1998.0122

Ivanochko, T. S., and Pedersen, T. F. (2004). Determining the influences of Late Quaternary ventilation and productivity variations on Santa Barbara Basin sedimentary oxygenation: a multi-proxy approach. Quat. Sci. Rev. 23, 467-480. doi: 10.1016/i.quascirev.2003.06.006

Kallel, N., Labeyrie, L. D., Juillet-Leclerc, A., and Duplessy, J. C. (1988). A deep hydrological front between intermediate and deep-water masses in the glacial Indian Ocean. Nature 333, 651-655. doi: 10.1038/333651a0

Klump, J., Hebbeln, D., and Wefer, G. (2000). The impact of sediment provenance on barium-based productivity estimates. Mar. Geol. 169, 259-271. doi: 10.1016/S0025-3227(00)00092-X

Meyers, P. A. (1997). Organic geochemical proxies of paleoceanographic, plaeolimnologic, and plaeoclimatic processes. Org. Geochem. 27, 213-250.

Morford, J. L., and Emerson, S. (1999). The geochemistry of redox sensitive trace metals in sediments. Geochim. Cosmochim. Acta 63, 1735-1750. doi: 10.1016/S0016-7037(99)00126-X

Morford, J. L., Russell, A. D., and Emerson, S. (2001). Trace metal evidence for changes in the redox environment associated with the transition from terrigenous clay to diatomaceous sediment, Saanich Inlet, BC. Mar. Geol. 174, 355-369. doi: 10.1016/S0025-3227(00)00160-2

Murray, R. W., and Leinen, M. (1993). Chemical transport to the seafloor of the equatorial Pacific Ocean across a latitudinal transect at $135^{\circ} \mathrm{W}$ : tracking sedimentary major, trace, and rare earth element fluxes at the Equator and the Intertropical Convergence Zone. Geochim. Cosmochim. Acta 57, 4141-4163. doi: 10.1016/0016-7037(93)90312-K

Murray, R. W., and Leinen, M. (1996). Scavenged excess aluminum and its relationship to bulk titanium in biogenic sediment from the central equatorial Pacific Ocean. Geochim. Cosmochim. Acta 60, 3869-3878. doi: 10.1016/0016-7037(96)00236-0 
Naidu, P. D., and Malmgren, B. A. (1996). A high-resolution record of late Quaternary upwelling along the Oman Margin, Arabian Sea based on planktonic foraminifera. Paleoceanography 11, 129-140.

Naimo, D., Adamo, P., Imperato, M., and Stanzione, D. (2005). Mineralogy and geochemistry of a marine sequence, Gulf of Salerno, Italy. Quat. Int. 140-141, 53-63. doi: 10.1016/j.quaint.2005.05.004

Naqvi, S. W. A. (1987). Some aspects of the oxygen-deficient conditions and denitrification in the Arabian Sea. J. Mar. Res. 45, 1049-1072. doi: $10.1357 / 002224087788327118$

Naqvi, W. A., Charles, C. D., and Fairbanks, R. G. (1994). Carbon and oxygen isotopic records of benthic foraminifera from the Northeast Indian Ocean: implications on glacial-interglacial atmospheric $\mathrm{CO}_{2}$ changes. Earth Planet. Sci. Lett. 121, 99-10.

Nath, B. N. (2001). Geochemistry of Sediments. New Delhi: Oxford \& IBH.

Nesbitt, H. W., and Markovics, G. (1997). Weathering of granodioritic crust, longterm storage of elements in weathering profiles, and petrogenesis of siliciclastic sediments. Geochim. Cosmochim. Acta 61, 1653-1670.

Pailler, D., Bard, E., Rostek, F., Zheng, Y., Mortlock, R., and Van Geen, A. (2002). Burial of redox-sensitive metals and organic matter in the equatorial Indian Ocean linked to precession. Geochim. Cosmochim. Acta 66, 849-865. doi: 10.1016/S0016-7037(01)00817-1

Pattan, J. N., and Pearce, N. J. G. (2009). Bottom water oxygenation history in southeastern Arabian Sea during the past 140 ka: results from redoxsensitive elements. Palaeogeogr. Palaeoclimatol. Palaeoecol. 280, 396-405. doi: 10.1016/j.palaeo.2009.06.027

Pattan, J. N., Mir, I. A., Parthiban, G., Karapurkar, S. G., Matta, V. M., Naidu, P. D., et al. (2013). Coupling between suboxic condition in sediments of the western Bay of Bengal and southwest monsoon intensification: a geochemical study. Chem. Geol. 343, 55-66. doi: 10.1016/j.chemgeo.2013.02.011

Pedersen, T. F., and Price, N. B. (1982). The geochemistry of manganese carbonate in Panama Basin sediments. Geochim. Cosmochim. Acta 46, 59-68. doi: 10.1016/0016-7037(82)90290-3

Piotrowski, A. M., Banakar, V. K., Scrivner, A. E., Elderfield, H., Galy, A., and Dennis, A. (2009). Indian Ocean circulation and productivity during the last glacial cycle. Earth Planet. Sci. Lett. 285, 179-189. doi: 10.1016/j.epsl.2009.06.007

Piper, D. Z., and Perkins, R. B. (2004). A modern vs. Permian black shale - the hydrography, primary productivity, and water-column chemistry of deposition. Chem. Geol. 206, 177-197. doi: 10.1016/j.chemgeo.2003.12.006

Punyu, V. R., Banakar, V. K., and Garg, A. (2014). Equatorial Indian Ocean productivity during the last $33 \mathrm{kyr}$ and possible linkage to Westerly Jet variability. Mar. Geol. 348, 44-51. doi: 10.1016/j.margeo.2013.11.010

Rajendran, A., Kumar, M. D., and Bakker, J. F. (1992). Control of manganese and iron in Skagerrak sediments (norheastern North sea). Chem. Geol. 98, 111-129.

Ramaswamy, V., and Gaye, B. (2006). Regional variations in the fluxes of foraminifera carbonate, coccolithophorid carbonate and biogenic opal in the Northern Indian Ocean. Deep. Res. Part I Oceanogr. Res. Pap. 53, 271-293. doi: 10.1016/j.dsr.2005.11.003

Rao, V. P., Kessarkar, P. M., Thamban, M., and Patil, S. K. (2010). Paleoclimatic and diagenetic history of the late quaternary sediments in a core from the Southeastern Arabian Sea: geochemical and magnetic signals. J. Oceanogr. 66, 133-146. doi: 10.1007/s10872-010-0011-2

Rashid, H., Flower, B. P., Poore, R. Z., and Quinn, T. M. (2007). A 25 ka Indian Ocean monsoon variability record from the Andaman Sea. Quat. Sci. Rev. 26, 2586-2597. doi: 10.1016/j.quascirev.2007.07.002

Reimer, P. J., Baillie, M. G. L., Bard, E., Bayliss, A., Beck, J. W., Blackwell, P. G., et al. (2009). IntCal09 and Marine09 radiocarbon age calibration curves, 0-50,000 years cal BP. Radiocarbon 51, 1111-1150. doi: 10.1017/S0033822200034202

Reimer, P. J., Bard, E., Bayliss, A., Beck, J. W., Blackwell, P. G., Ramsey, C. B., et al. (2013). IntCal13 and Marine13 radiocarbon age calibration curves 0-50,000 years cal BP. Radiocarbon 55, 1869-1887. doi: 10.2458/azu_js_rc.55. 16947

Rimmer, S. M. (2004). Geochemical paleoredox indicators in DevonianMississippian black shales, Central Appalachian Basin (USA). Chem. Geol. 206, 373-391. doi: 10.1016/j.chemgeo.2003.12.029
Rostek, F., Bard, E., Beaufort, L., Sonzogni, C., and Ganssen, G. (1997). Sea surface temperature and productivity records for the last $240 \mathrm{kyr}$ on the Arabian Sea. Deep. Res. Part II Top. Stud. Oceanogr. 44, 1461-1480. doi: 10.1016/S0967-0645(97)00008-8

Sarkar, A., Bhattacharya, S. K., and Sarin, M. M. (1993). Geochemical evidence for anoxic deep water in the Arabian Sea during the last glaciation. Geochim. Cosmochim. Acta 57, 1009-1016. doi: 10.1016/0016-7037(93)90036-V

Schmiedl, G., and Leuschner, D. C. (2005). Oxygenation changes in the deep western Arabian Sea during the last 190,000 years: productivity versus deepwater circulation. Paleoceanography 20, 1-14. doi: 10.1029/2004PA001044

Schott, F. A., and McCreary, J. P. (2001). The monsoon circulation of the Indian Ocean. Prog. Oceanogr. 51, 1-123. doi: 10.1016/S0079-6611(01)00 083-0

Schroeder, J. O., Murray, R. W., Leinen, M., Pflaum, R. C., and Janecek, T. R. (1997). Barium in equatorial Pacific carbonate sediment: terrigenous, oxide, and biogenic associations. Paleoceanography 12, 125-146.

Shetye, S. S., Sudhakar, M., Mohan, R., and Jena, B. (2014). Contrasting productivity and redox potential in Arabian Sea and Bay of Bengal. J. Earth Sci. 25, 366-370. doi: 10.1007/s12583-014-0415-9

Southon, J., Kashgarian, M., Fontugne, M., Metivier, B., and Yim, W. W.-S. (2002). Marine reservoir corrections for the Indian Ocean and Southeast Asia. Radiocarbon 44, 167-180. doi: 10.1017/S0033822200064778

Stuiver, M., Reimer, P. J., and Braziunas, T. F. (1998). High-precision radiocarbon age calibration for terrestrial and marine samples. Radiocarbon 40, 1127-1151. doi: $10.1017 / S 0033822200019172$

Taylor, S., and McLennan, S. (1995). The geochemical evolution of the continental crust. Rev. Geophys. 33, 241-265. doi: 10.1029/95RG00262

Timothy, D., and Calvert, S. (1998). Systematics of variations in excess A1 and $\mathrm{A} 1 / \mathrm{Ti}$ in sediments from the central equatorial Pacific. Paleoceanography 13, $127-130$.

Tiwari, M., Ramesh, R., Somayajulu, B. L. K., Jull, A. J. T., and Burr, G. S. (2006). Paleomonsoon precipitation deduced from a sediment core from the equatorial Indian Ocean. Geo Mar. Lett. 26, 23-30. doi: 10.1007/s00367-005-0012-0

Tomczak, M., and Godfrey, J. S. (eds.). (2003). Regional Oceanography: An Introduction. Oxford, UK: Pergamon.

Tribovillard, N., Algeo, T. J., Lyons, T., and Riboulleau, A. (2006). Trace metals as paleoredox and paleoproductivity proxies: an update. Chem. Geol. 232, 12-32. doi: 10.1016/j.chemgeo.2006.02.012

Tribovillard, N., Riboulleau, A., Lyons, T., and Baudin, F. (2004). Enhanced trapping of molybdenum by sulfurized marine organic matter of marine origin in Mesozoic limestones and shales. Chem. Geol. 213, 385-401. doi: 10.1016/j.chemgeo.2004.08.011

Tyson, R. V., and Pearson, T. H. (1991). Modern and ancient continental shelf anoxia: an overview. Geol. Soc. Lond. Spec. Publ. 58, 1-24. doi: 10.1144/GSL.SP.1991.058.01.01

Vidya, P. J., Prasanna Kumar, S., Gauns, M., Verenkar, A., Unger, D., and Ramaswamy, V. (2013). Influence of physical and biological processes on the seasonal cycle of biogenic flux in the equatorial Indian Ocean. Biogeosciences 10, 7493-7507. doi: 10.5194/bg-10-7493-2013

Wei, G., Liu, Y., Li, X., Shao, L., and Liang, X. (2003). Climatic impact on Al, K, Sc and $\mathrm{Ti}$ in marine sediments: evidence from ODP Site 1144, South China Sea. Geochem. J. 37, 593-602. doi: 10.2343/geochemj.37.593

Whitfield, M. (2001). Interactions between phytoplankton and trace metals in the ocean. Adv. Mar. Biol. 41, 1-128. doi: 10.1016/S0065-2881(01)41002-9

Conflict of Interest Statement: The authors declare that the research was conducted in the absence of any commercial or financial relationships that could be construed as a potential conflict of interest.

Copyright (C) 2017 Chandana, Bhushan and Jull. This is an open-access article distributed under the terms of the Creative Commons Attribution License (CC BY). The use, distribution or reproduction in other forums is permitted, provided the original author(s) or licensor are credited and that the original publication in this journal is cited, in accordance with accepted academic practice. No use, distribution or reproduction is permitted which does not comply with these terms. 